
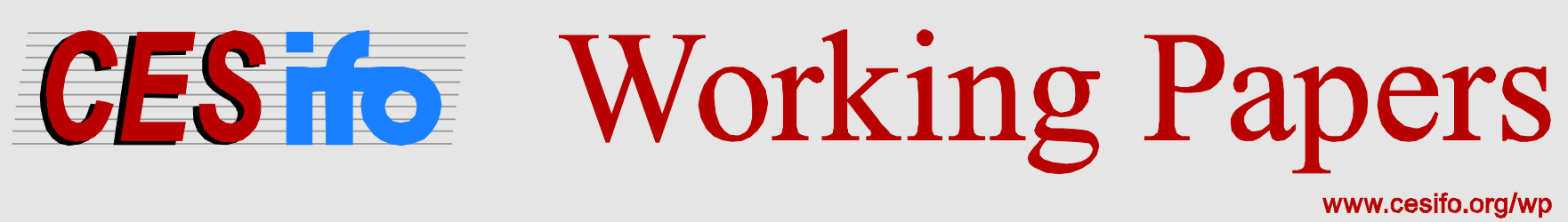

\title{
One Pillar Crumbling, the Others too Short: Old-Age Provision in Germany
}

\author{
Martin Werding
}

CESIFO WORKING PAPER NO. 5760

CATEgORY 3: SOCIAL PROTECTION

FEBRUARY 2016
An electronic version of the paper may be downloaded
- from the SSRN website: Www.SSRN.com
- from the RePEc website: Www.RePEc.org
- from the CESifo website: www.CESifo-group.org/wp




\title{
One Pillar Crumbling, the Others too Short: Old-Age Provision in Germany
}

\begin{abstract}
Public pay-as-you-go pensions still form the dominant pillar of old-age provision in Germany. This is in marked contrast to the situation in Anglo-Saxon countries. It has advantages if labour markets are strong, e.g., following a quick recovery from the Great Recession. It has disadvantages, as Germany will be ageing very rapidly in the near future. Following a series of reforms, benefit levels will decline, while contribution rates still go up, and additional cover from private or occupational pension schemes is urgently needed. Thus far, steps in this direction have been half-hearted, and the financial crisis impedes a further shift. Nevertheless, despite the differing traditions, important aspects in current debates now converge to those discussed in the UK or the US.
\end{abstract}

JEL-codes: E270, G280, H550, J110, J260.

Keywords: old-age provision, public pensions, occupational pensions, pre-cautionary saving, demographic ageing, pension reform, simulations.

\author{
Martin Werding \\ Chair in Social Policy and Public Finance \\ Ruhr-University Bochum \\ Department of Social Science \\ Germany - 44780 Bochum \\ martin.werding@ruhr-uni-bochum.de
}

February 2016 


\section{Introduction}

With its „Bismarckian“ tradition, old-age provision in Germany has followed a path which is widely different from Anglo-Saxon approaches which are combining "Beveridgean" flat-rate pensions or degressive ${ }^{1}$ social-security benefits with various forms of supplementary cover that is mostly provided on a private basis. However, responding to long-term challenges such as demographic ageing, the German system has undergone substantial changes during the last two decades and is in fact still under re-construction. The continuing crisis in financial markets and a more profound distrust in financial institutions and market-based instruments of old-age provision currently create obstacles for going ahead in this overhaul.

The aim of this paper is to provide a comprehensive description of the current situation and future perspectives for the overall system of old-age provision in Germany. Against this background, we will demonstrate that the agenda for further reforming the system is particular in some respects, but that issues which need to be discussed converge to those in the UK or the US. First, we will deal with the public, or first-pillar, pension scheme (Section 2). Following a series of reforms, it currently benefits from strong labour-market performance, but is heavily challenged because demographic ageing will enter an acute phase soon. Then, we will turn to the second and third pillar (Section 3), discussing the role they have been assigned in the course of these reforms and the problems that have surfaced. Our considerations are illustrated using long-term projections for the pension budget and individual-level outcomes under variable assumptions. Section 4 concludes, summarizing what has been achieved to stabilize old-age provision in Germany as well as the options for what remains to be done.

\section{The first pillar: Statutory Pension Insurance}

\subsection{Basic principles and the reforms taken thus far}

Public pay-as-you-go pensions provided by Statutory Pension Insurance (gesetzliche Rentenversicherung, GRV) ${ }^{2}$ are still the dominant pillar within the German system of old-age provision. As a distinct feature regarding the Bismarck-vs-Beveridge classification (Pestieau 2006, ch. 5), pensions provided by the scheme are strongly earnings-related (and conditioned on the number of years covered with contributions). Certainly until the late 1990s, they were meant to contribute in a substantial fashion to

1 This refers to the fact that, in the US Social Security scheme, indexed average life-time earnings are converted into benefit entitlements using a degressive scale, with a progressive effect for the "implicit tax" involved in earnings-related contributions (Fenge and Werding 2004). We are well aware that these institutional features may be modified or even reversed by typical differences in retirement age and life expectancy related to income (Coronado et al. 2000). Similar things were true for the British State Second Pension scheme which has been in place from 2002 to 2016, providing supplementary, earnings-related pensions on a voluntary basis (i.e., with a "contracting-out” option). Also, British State Basic Pensions with compulsory membership rules are not a genuine flat rate, as they are assessed taking into account the number of qualifying years (but not the level of covered earnings). This remains to be true for the "New State Pension" which replaces basic and second pensions (and older forms of additional state pensions) starting from April 2016, with compulsory cover at a higher level than through the traditional basic pension alone.

2 In graphs and tables, I will occasionally use the shorthand "GRV" which is very common in Germany. 
maintaining earlier living standards of members with full earnings records. Participation in the scheme is mandatory for a majority of workers, depending on their precise employment status. ${ }^{3}$ This applies to about 75 percent of the current labour force, while, building on their life-long social-insurance records, more than 90 percent of those aged 65 and older receive some amount of public old-age pensions (linked to at least 5 qualifying years). Benefit assessment is based on a "points system” (Robalino and Bodor 2007) which translates individual work records and life-time earnings into old-age pension entitlements. ${ }^{4}$ Point values and, hence, benefits are up-rated using a complex indexation rule we will describe below. Implicitly, this rule also applies to the valorization of life-time earnings, as there is no distinction between benefits at award and after award. Therefore, annual up-ratings have far-reaching consequences for the level of benefits (compared to current wages) or for individual replacement rates.

The Statutory Pension scheme has been openly unfunded since the 1950s. As a consequence, its budgetary situation and financial outlook are directly linked (i) to the performance of domestic labour markets and (ii) to the demographic structure of the resident population. Both aspects played a major role for triggering reforms which have taken effect during the last two decades. Over the years, demographic ageing has become more and more prominent as a reason for discussing further steps to reform. But a long-lasting increase in "structural” unemployment which was re-inforced, but clearly not caused, by German unification was another major driver behind the reforms which took place in the 1990s and early 2000s. In terms of the instruments applied, the reforms which have been enacted in several rounds share major ingredients with pension reforms taken in other developed countries (Diamond 2002; Disney 2003; Martin and Whitehouse 2008; Meier and Werding 2010).

Initially, a number of changes were made to strengthen actuarial fairness. With the traditional setup of the scheme, however, room for manœuvre was limited in this respect. Worth mentioning is that a privileged treatment of periods of education in benefit assessment was mostly abolished already in 1992 (with respect to newly awarded pensions); the same applies to relatively weak elements of redistribution in favour of low-wage earners with long work records; access to disability benefits was tightened at the same time, and survivor benefits were reduced later on. Probably the most important measures of this type were steps to strengthening age 65 as a uniform, statutory retirement age for both men and women through the introduction of permanent reductions of benefits in virtually all cases of earlier retirement. This became effective only gradually starting from 1997, when it had become fully apparent that early retirement was a misguided strategy for dealing with high levels of unemployment. ${ }^{5}$ Also, starting from 1998, regular financial injections into the Statutory Pension

3 Important exemptions relate to civil servants (a particular sub-group of public-sector employees), to the selfemployed (some of which have to be members of the public scheme for a limited number of years, while others have mandatory private cover and yet others have to make private provisions on a voluntary basis), and to individuals who are working for a monthly pay of less than the lower earnings limit of 450 Euro (in so-called "mini jobs”). There is also an upper limit for covered earnings at around 6,000 Euro per month; no contributions are payable on higher earnings, but they are also neglected when assessing benefits.

4 Special rules apply to disability pensions for which work records are fictitiously extended. Survivor pensions are derived, basically as a certain percentage, from benefit entitlements of the deceased.

5 Overwhelming international evidence on this issue is collected in Gruber and Wise (2010). 
scheme financed from the federal-government budget were massively expanded. This state subsidy was officially meant to cover expenditure on non-contributory benefits but was also used as a means for relaxing the tension between current benefit levels and current contribution rates which is inherent in any pay-as-you-go scheme.

The traditional logic of providing a pre-defined level of benefits was modified through a series of changes in the rules governing benefit up-ratings ${ }^{6}$ which eventually lead to a partial switch to NDC, that is, to a system with "notionally defined contributions” (Disney 1999; Börsch-Supan 2005). While annual up-ratings were originally based on pure gross-wage indexation (until 1991) and then on different variants of net-wage indexation (from 1992 respectively 2001 onwards), the current rule (established in 2004) takes into account the following elements (each with a one-period time lag):

- changes in gross wages,

- changes in pension contribution rates (and in a "recommended" rate of private precautionary savings; see Section 3.1),

- and changes in the system-dependency (i.e., pensioner-to-contributor) ratio.

This latter element, called "sustainability factor", establishes an automatic adjustment of benefit levels to adverse demographics, effectively sharing the growing burden of demographic ageing between retired and active individuals. The immediate effects of any of these changes for pension finances were small. Yet, when applied over longer periods of time and into the future, they make an enormous difference with respect to total pension expenditure. As the same is true with respect to future levels of individual benefit entitlements, it was in the context of the 2001 reform that politicians also embarked on a move towards higher pre-funding. However, they decided to do this outside the realm of social insurance (see Section 3). ${ }^{7}$

Last but not least, an increase in the statutory retirement age was enacted in 2007. From 2012 to 2029, the age threshold for claiming full benefits will gradually rise from 65 to 67 years, again combined with reductions of benefits for those who retire (in regular cases: up to 2 years) earlier. ${ }^{8}$ In the greater public, this change is still highly controversial. In 2014, the government made a small step in the opposite direction, reducing the age for claiming full benefits by 2 years for a particular subgroup of workers with extremely long work records (see Section 2.2).

\subsection{Strengths if labour markets are performing well}

The institutional set-up of pay-as-you-go pension schemes with earnings-related benefits has its weaknesses and its strengths. Potential strengths can be seen, for instance, in how the German public

\footnotetext{
6 See Werding (2007) for a brief description, Gasche and Kluth (2011) for an in-depth treatment.

7 The Statutory Pension scheme only holds a tiny amount of financial reserves, just enough to cover pension expenditure for between 0.2 and 1.5 months - that is, for less than one week to about six weeks. The reserves are meant to isolate the system against business-cycle fluctuations of regular strength and duration and to stabilize contribution rates in the short run.

8 Apart from the change in the relevant age threshold, the system of benefit reductions (or increases in cases when retirement is postponed) remained unchanged. The rate of reductions is 3.6 percent (increases: 5 percent) per year - too low to be actuarially fair and to neutralize financial incentives to retire early.
} 
pension scheme fared through the Great Recession and the following period of turmoil in financial markets which still has not cleared away. Before the crisis, a continued up-ward trend in unemployment which can be traced back to the 1970s had created ever-growing pressure on public finances, including the budget of Statutory Pension Insurance. However, this trend changed its direction in 2005/06. When the financial crisis reached the real economy in 2008/09, there were fears that this short period of recovery would be stalled. Germany was hit by a downturn of aggregate demand and production which was even stronger than in most other developed countries. From 2008 to 2009, real GDP fell by 5.6 percent (United States: $-2.8 \%$; United Kingdom: $-4.2 \%$; Japan: $-5.5 \%$; OECD 2015) which created an enormous risk for employment, while wage growth practically stopped.

For the public pension scheme, these prospects could have implied the following effects (BörschSupan et al. 2009; 2010). Since lower employment and lower wage growth reduce the tax base from which pension expenditure is financed, contribution rates would have tended to increase (once existing reserves had been depleted). At the same time, lower wage growth and higher contribution rates reduce benefit up-ratings (due to the net-wage component of the indexation rule), which would have taken away some of the pressure on pension finances; higher system dependency resulting from lower employment would have reinforced this effect. Additional effects working in opposite directions might have been produced by the rules for adjusting the state subsidy ${ }^{9}$ and by a special clause ruling out nominal reductions in pension benefits. ${ }^{10}$ In any case, there was a real danger that both contribution rates and benefit levels would be temporarily increased until around 2020, while wages and, hence, pension benefits would be reduced on absolute terms as a lasting effect.

In reality, however, not much of this has actually materialized. The crisis suspended the on-going decline in unemployment only for a few months, in 2009. The downward trend continued immediately afterwards (see Figure 1), so that current rates are now the lowest since the early 1980s. GDP and wages grew at accelerated rates after 2009, with a tendency to quickly closing the gaps vis-à-vis their earlier growth paths. Even pension benefits which follow these developments only with a delay and are subject to a number of moderating factors have started to increase at higher rates; the 2016 uprating (by more than 4 percent, partly due to a statistical extra-effect) is expected to be the highest in more than 20 years. There is of course no genuine counterfactual for what would have happened in the absence of the crisis. But the data support the impression that all consequences that directly matter for the pension budget were surprisingly small and basically only temporary in their nature.

While unemployment started decreasing only after 2005, labour-force participation has increased steadily since the early 1990s. Among those aged 15 to 64, it has gone up from about 81 percent to

9 The state subsidy is adjusted annually, partly in line with wages and partly in line with contribution rates, creating mixed effects of the same type as those explained above.

10 This clause was introduced in 2009 as an ad-hoc amendment of pension law to protect current pensioners against unfavourable short-term effects of the crisis. It stated that, even if nominal wages declined, pension benefits would be held constant on nominal terms, with compensations through lower benefit up-ratings in subsequent years. The rule was actually used in 2010. Ex ante, it was unclear whether compensations would be applied later on, but it turned out that this was indeed the case and that the resulting increase in the benefit level was perfectly neutralized. 
Figure 1: Unemployment, wages and benefits (1991-2015)

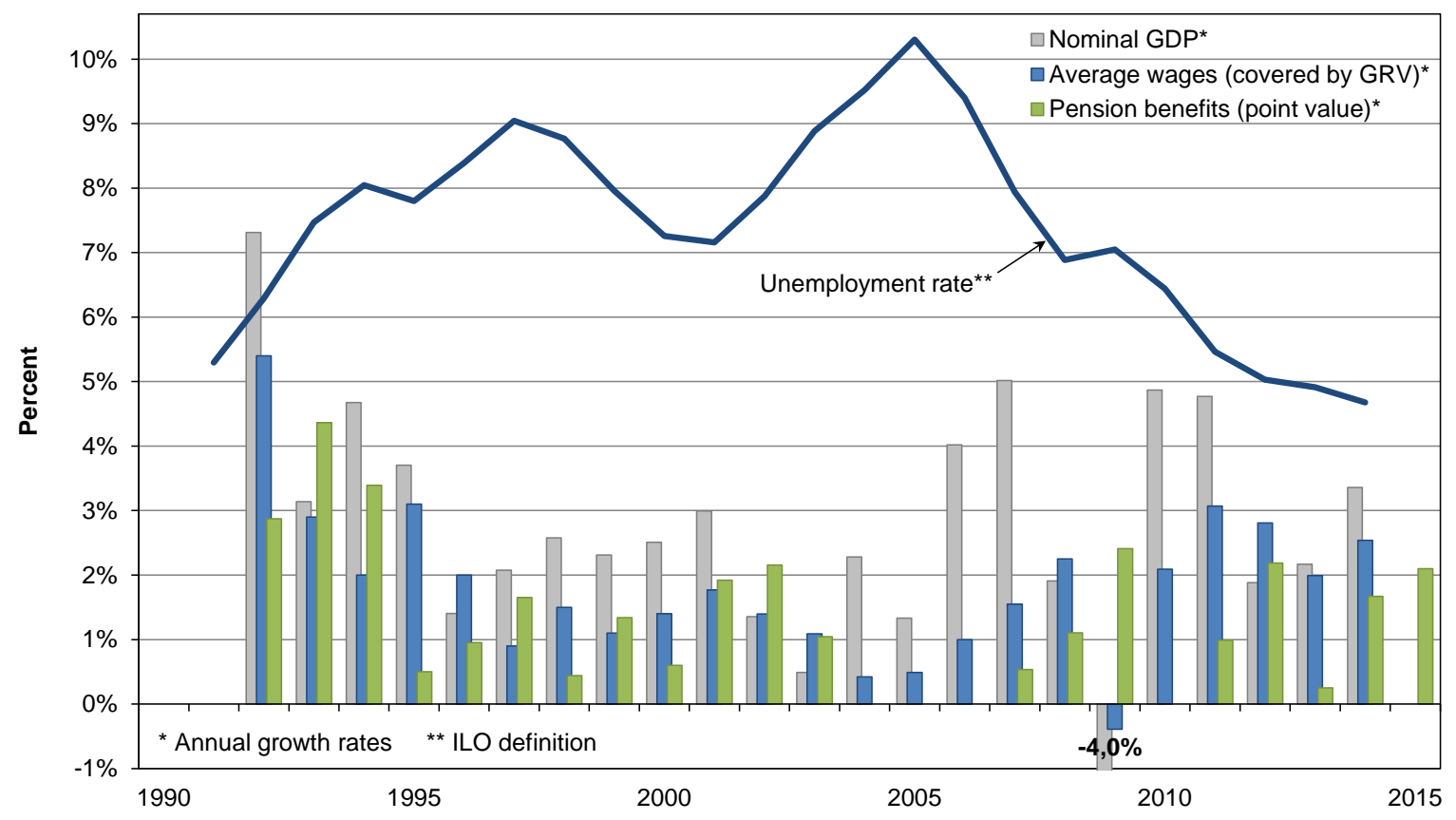

Sources: Federal Employment Agency; Federal Statistical Office; German Pension Insurance; own calculations.

85 percent for males and from 64 percent to 78 percent for females. Therefore, the labour force and total employment are now at unprecedented highs in absolute figures. The same is true even for employment subject to the Statutory Pension scheme which, due to adverse incentives to seek cover there, had been declining from 1991 to 2005, but is on the rise again since then.

Another remarkable trend has been the increase in labour-force participation among older workers. While, compared to other developed countries, it has been rather low some 20 years ago, it is now among the highest in the OECD world. Currently, participation rates among those aged 55 to 59 exceed 80 percent, coming close to average figures for the entire working-age population, and among those aged 60 to 64 they are now just above 60 percent (see Figure 2). The share of employment covered by Statutory Pension Insurance is lower, but it has also increased against the 1990s, especially for the 60-to-64 age group. In recent years, these changes may have been fuelled by improved labourmarket performance, but they also point to more profound changes in incentives to retire early (see Section 2.1) and in the way individuals prepare for the consequences of demographic ageing. As a result, average retirement age for old-age pensions provided by the Statutory Pension scheme stopped a long-term decline in the second half of the 1990s and has gone up by 2 years since then. While the statutory age threshold has reached 65 years and 3 months in 2014, actual retirement age is now 64 years and 2 months. ${ }^{11}$ As the former figure will be gradually scaled up to 67 over the next 15 years, the latter should be expected to continue increasing.

11 There is an alternative definition of average retirement age including disability pensions which is just above 61 years, so substantially lower for obvious reasons. But it is less telling regarding behavioural changes, since disability benefits are basically not used as a pathway into early retirement in Germany. 
Figure 2: Labour-force participation at higher ages and retirement age (1991-2014)

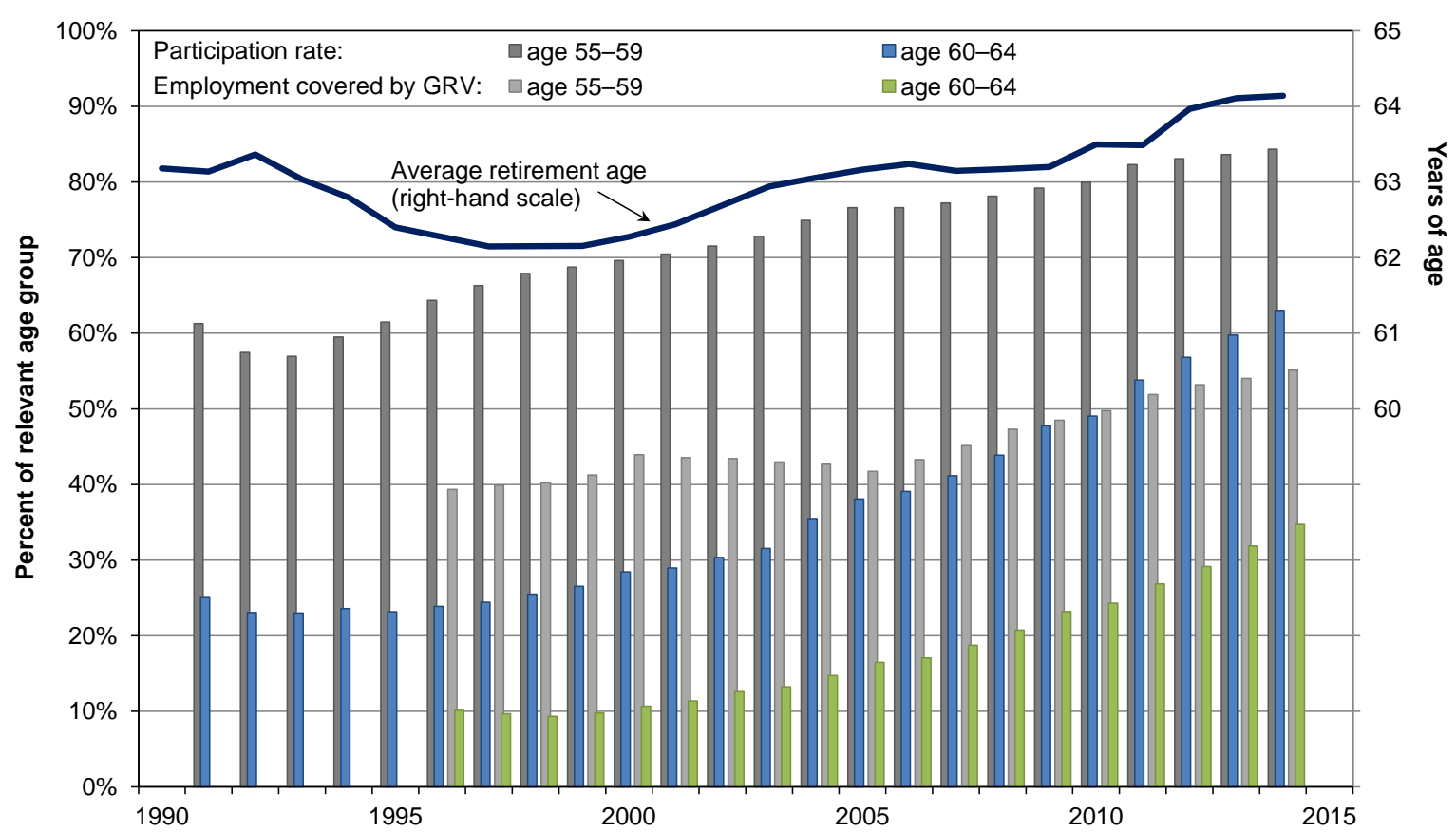

Sources: Federal Employment Agency; Federal Statistical Office; German Pension Insurance; own calculations.

Following all the developments described here, the German Statutory Pension scheme is currently in a rather favourable budgetary situation, even though this cannot be expected to last for long (see Section 2.3). This has in fact created a temptation for politicians to relax their strict course of reforming the system. In 2014, financial reserves of the pension scheme were filled up to their legal limits. Therefore, for the first time in many years, the current grand-coalition government introduced additional types of benefit entitlements which may not be excessively costly (Werding 2014) but will still be effective when demographic ageing becomes really acute. Among this package, moderate increases in disability benefits can be justified as a protective measure for a group which is particularly vulnerable during the process of on-going adjustments. But the same cannot be claimed for other measures, such as increases in child-related benefit entitlements ${ }^{12}$ or a privileged access to early retirement (at age 63, without any reductions in benefits) for workers with very long work records. ${ }^{13}$ These are the most expensive elements of the reform, but they do not address actual challenges and are partly at odds with earlier reform trends, with the risk of undermining their credibility.

\subsection{The challenge of demographic ageing}

While the link of the public pension scheme to labour-market performance turned out to be a strength in recent years, the dependence on domestic demographics definitely involves a severe challenge.

12 Introducing or expanding child-related benefits in pay-as-you-go pension schemes is clearly defendable as a way to restoring incentives to have children and invest in their human capital - which is how these systems are actually “pre-funded” (Cigno and Werding 2007). Here, however, higher benefits were targeted at mothers of children born before 1992, so that there can be no incentive effects.

13 Börsch-Supan et al. (2015) show that these workers do not only have much higher benefit entitlements but are also much healthier than average individuals who are just about to enter retirement. 
Demographic ageing will become more pressing soon and will fully unfold over the next twenty to thirty years. Compared to other developed countries, this process is particularly strong in Germany. The drivers are the same as everywhere in the developed world. The on-going increase in life expectancy that is expected to continue is of a regular order of magnitude. However, following a "baby boom" which was rather late and relatively small, the total fertility rate fell to 1.4 (children per woman) already in the first half of the 1970s; in West Germany, it has remained basically constant at this very low level; in East Germany, it showed some fluctuations around this figure after 1980 and in the aftermath of unification, but has now fully adjusted to the West German level.

Therefore, old-age dependency will almost double until about 2035; it may then remain stable or increase even further at a more moderate speed (see Appendix A.1). Variations in the underlying assumptions that appear to be realistic will not alter these trends substantially over the next two to three decades. The demographic outlook for Germany is thus that the population will start continuously shrinking and ageing soon, with each new generation being about two thirds the size of the preceding one. It therefore needs an overall system of old-age provision which is adapted to this difficult situation, i.e., which is financially sustainable and will nevertheless deliver adequate benefits at reasonable conditions.

Given the scale of demographic ageing, the Statutory Pension scheme, with its pure pay-as-yougo financing, will be less and less able to make a substantial contribution to securing earlier living standards of pensioners - at least, not at affordable contribution rates for active workers. This has been its ambition until about the mid-1990s, when it provided for a gross replacement rate of 50 percent (translating into a net replacement rate of about 70 percent). ${ }^{14,15}$ Since then, a major element of the reforms that followed (see Section 2.1) was to gradually reduce the level of future pension benefits in order to keep the contribution rate under control. Figure 3 shows the implications of the current legal framework for gross replacement rates and contribution rates - two key indicators for the financial situation of the scheme and its impact on pensioners and contributors - in the period until 2060 under assumptions for what is considered a meaningful "baseline scenario". ${ }^{16}$

Under current rules, the gross replacement rate can be roughly stabilized until 2030 at a level which is already 5 percentage points, or 10 percent, lower than around 1995. At the same time, the

14 These figures are based on pension benefits deriving from a full earnings record with 45 qualifying years at average earnings compared to average earnings of current contributors, including (or, alternatively, net of) all income taxes and social insurance contributions; they are thus "quasi-replacement rates”. By the strong taxbenefit link involved in the scheme, gross replacement rates are uniform at any level of covered wages.

15 Measuring benefit levels on a net basis would be clearly more informative. Nevertheless, we look at gross figures here as, otherwise, projections for contribution rates of other branches of social insurance would have to be conducted (and explained) as well. The same applies to income tax rates. In addition, the latter are strongly dependent on levels of (total) retirement income, so that average figures are not very telling.

16 The simulations have been prepared using the Social Insurance Model, version 2013 ("SIM.13"; described in Werding 2013) which is used on a regular basis for monitoring the long-term prospects for age-related public expenditure and general-government public finances in Germany (e.g., on behalf of the Federal Ministry of Finance or the Council of Economic Advisors; Werding 2014; 2016). The model entails a macro-level production function and exploits empirical literature on links between tax rates and employment to include some of the most important endogenous adjustments to the impact of ageing. Intermediate results for labourmarket performance and economic growth in the "baseline scenario" are summarized in Appendix A.2. 
Figure 3: Statutory Pension Insurance - Benefits and Contributions ("baseline scenario" and sensitivity tests, 1991-2060)

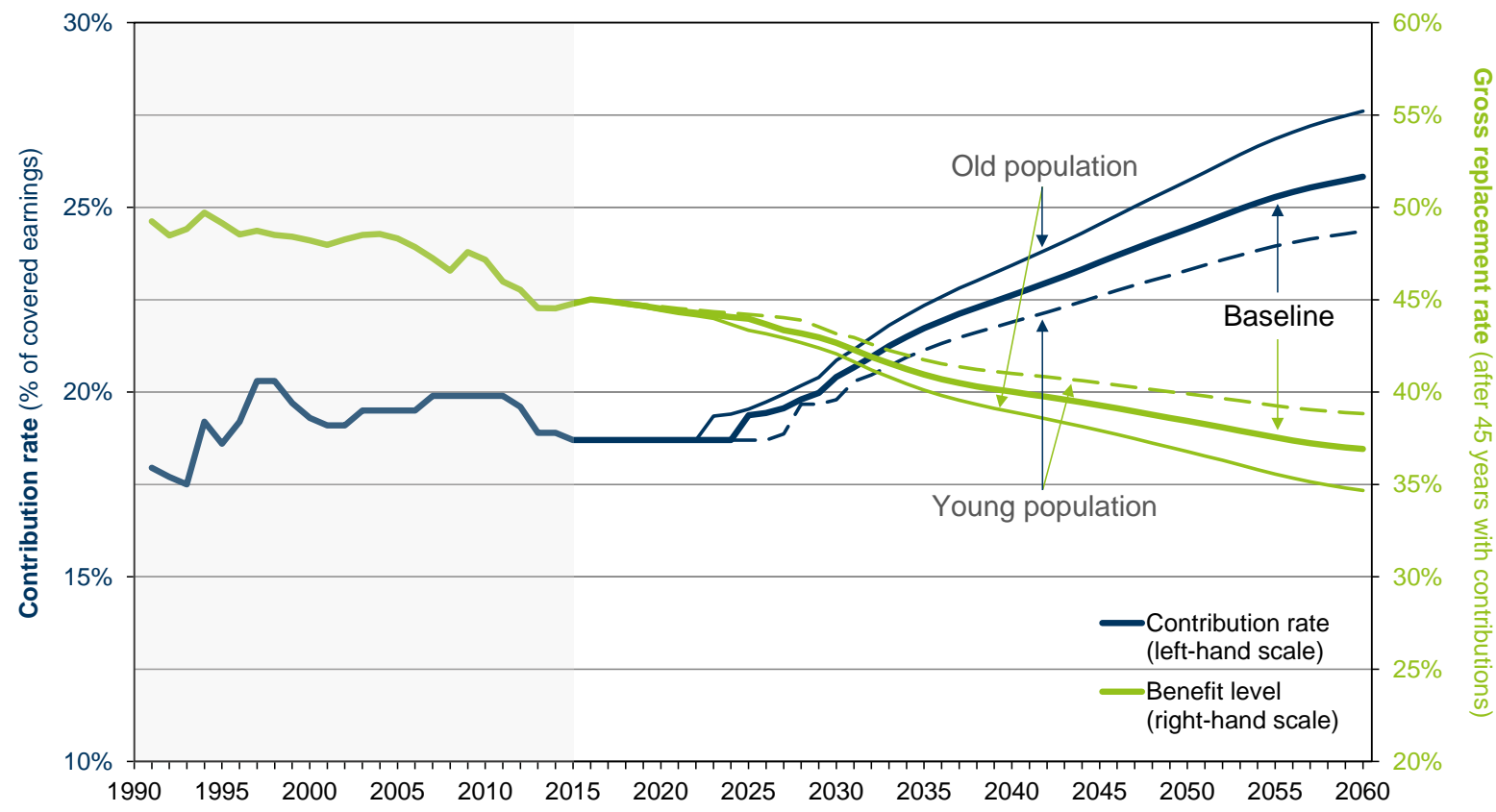

Sources: German Pension Insurance; SIM.13.

contribution rate may remain constant (at 18.7 percent) until around 2025. Afterwards, it will start increasing continuously. It can be expected to exceed 20 percent around 2030 and to reach 26 percent by 2060, while the benefit level drops by another 6 to 7 percentage points. It is thus probably fair to say that, in spite of all the reforms which have been taken, the scheme is still not prepared for what is projected to happen after 2030. In other words, it is still unclear what old-age provision will look like in Germany for those who are currently aged 50 or younger, and further reforms will be needed.

Of course, these simulations should never be taken as point estimates, but the fundamental trends they reveal are rather strong and robust. As a substitute for a larger number of sensitivity tests (e.g., regarding the role of participation rates, unemployment, productivity growth, etc.), ${ }^{17}$ two demographic variants are also considered which are rather extreme, one representing a "young” population, the other an "old" population (see Appendix A.1). The results suggest that immediate changes in demographic trends will make a difference towards the end of the projection period, but not until around 2040. Taken together, the two alternative scenarios may indicate a certain band of uncertainty around the baseline results, but the basic picture is always the same and never looks really good.

Figure 4 also displays the effects of the two most important steps to reform (see Section 2.1). Introducing the "sustainability factor" into the formula for benefit up-ratings (effective from 2005

17 Sensitivity of the results with respect to labour-force participation and labour-market performance is strong (as should be immediate from the discussion in Section 2.2). Changes in productivity growth would increase or decrease wages and pension benefits in terms of absolute figures. However, relative figures such as benefit levels or contribution rates would be largely unaffected, since benefits are regularly up-rated with a wagegrowth component. In an ageing society, therefore, higher productivity growth would not take away the financial pressure that arises, but it may make it easier to deal with this problem politically. 
Figure 4: Statutory Pension Insurance - Benefits and Contributions (earlier reforms, 1991-2060)

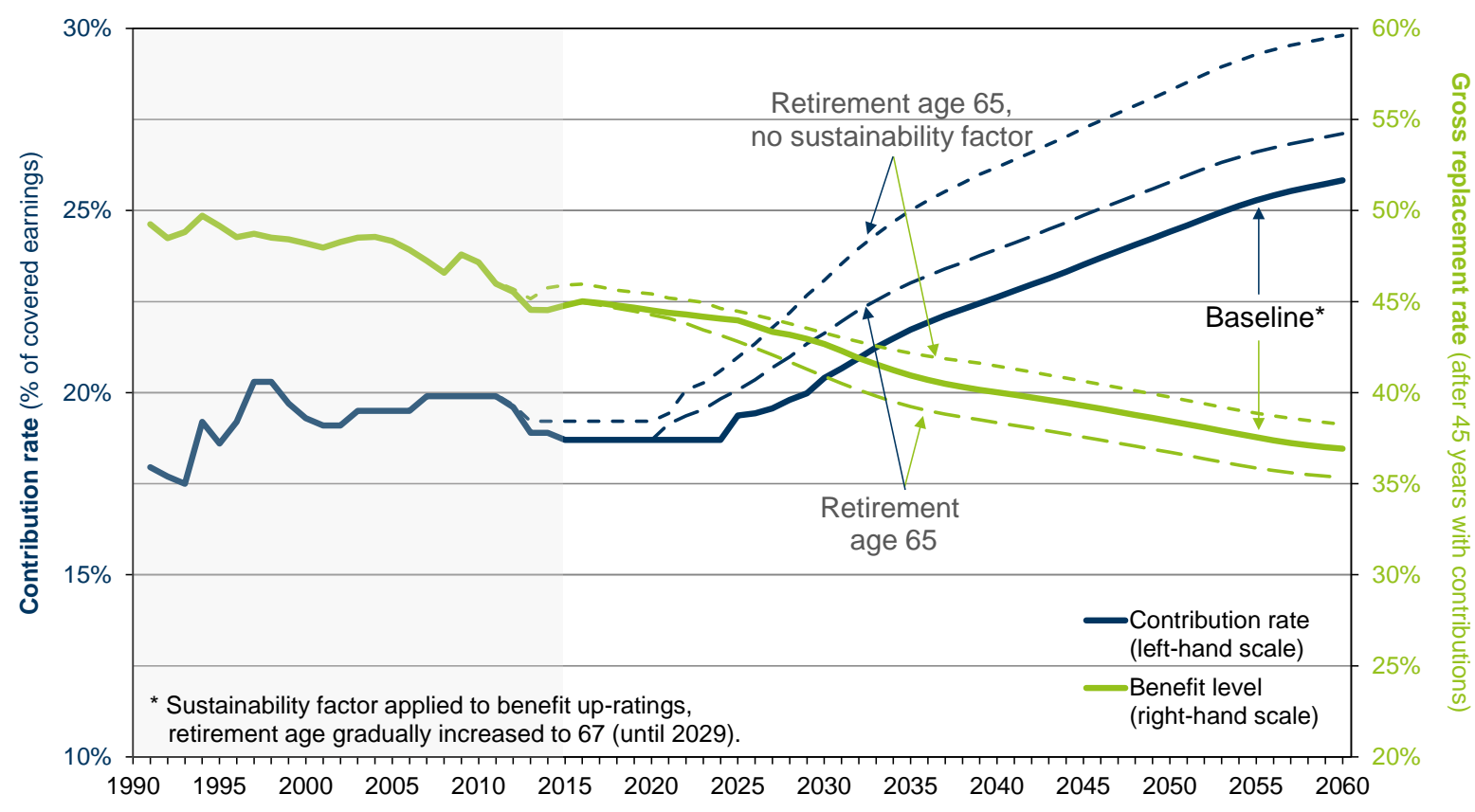

Sources: German Pension Insurance; SIM.13.

onwards) was a measure for directly scaling back the benefit level over the difficult time period ahead, with consequences for the contribution rate which are clearly favourable. Increasing the statutory retirement age (from 2012 onwards) turns out to be a more elegant approach, as it side-steps the simple algebra of pay-as-you-go systems. Since individual benefits will be paid out for a shorter time period (or will be subject to higher reductions if individuals retire early), annual benefit levels are actually increased vis-à-vis earlier rules, while contribution rates can be reduced nevertheless. Also, if "full” earnings records are gradually extended by up to two years, benefit levels will fully stabilize in the period until 2030 - an effect which is not captured in this graph (see Figure 5 below).

Therefore, and considering the on-going changes in labour-force participation of older workers (see Section 2.2), increasing the statutory retirement age beyond age 67 (which will be reached in 2029) definitely needs to be considered as a promising step to further reforming the public pay-as-yougo scheme. Ideally, this could be done by establishing an automatic link to increases in life expectancy, like the one already legislated in Denmark. Otherwise, there appears to be no way around further reductions in annual benefit levels to keep contribution rates within acceptable limits.

\section{Second and third-pillar pensions}

Given the gradual reduction in benefit levels prescribed by current rules, doing something to complement the first pillar of the German system of old-age provision and to provide for additional cover for a vast majority of workers should be a first-rate priority, for individuals and policy-makers alike.

If the pay-as-you-go mechanism meets serious limitations through adverse demographics, expanding institutions with pre-funded pension benefits is the only alternative which is available (Sinn 
2000). It is true that higher pre-funding of old-age provision does not necessarily lead to an increase in aggregate savings and real investment - hence, in future output (Barr 2002; Barr and Diamond 2006). However, with funded schemes, the direct link from pension finances to domestic employment and domestic demographics is dissolved. Funding creates possibilities to diversify the sources of old-age income in various ways, including the option of increasing (ownership in) real investment abroad. This may involve incurring new types of risk, but should go along with higher expected returns. Prefunding pensions is thus not unambiguously superior to pay-as-you-go financing (Breyer 1989; Fenge 1995; a straightforward demonstration is provided by Sinn 2000), but the two approaches are not equivalent, certainly not in the context of demographic ageing.

When successfully established, funding also alters the timing of when the burdens of actually financing pensions accrue. For quite a while, it may not reduce, but possibly increase the amount of current consumption forgone for active individuals through social insurance contributions and retirement savings. But it will reduce excessive costs of financing pensions which would otherwise arise in the future, implying an inter-temporal and inter-generational shift of existing burdens.

Besides the strong role of the public pay-as-you-go pension scheme, funded schemes located in the second pillar of old-age provision have a long tradition in Germany, less so purely private provisions which are usually classified as third pillar. In any case, provisions of both types have never been as important as they may now have to become. In the past, (supplementary) private provision was considered an issue mainly for the self-employed and for high-wage earners (whose wages are not fully covered in the Statutory Pension scheme). Occupational pensions were used more widely to top up public pensions of employees with high earnings or to stabilize employment among privileged subgroups of "core" employees. Over the 1980s and 1990s, the types of employer-based pension plans changed, but their overall diffusion did not really decline. Some employers closed old plans and did not introduce new ones to cut costs. Many others switched from DB to DC-type arrangements to avoid funding risks in much the same way as these things happened in other countries (Ehrentraut 2006, ch. 3 and 5; Markus 2007, ch. 5). By and large, this was the situation when the latest series of reforms of the public pension scheme was initiated.

\subsection{Private provision: Still in search for a useful framing}

Following years of debates about pension reforms as well as about necessary complements, in 2001 German law-makers finally agreed to strengthen supplementary, funded cover for old age. They defined a number of conditions which products should fulfil to qualify as "certified contracts” (e.g., no withdrawals before age 62; at least 70 percent of accumulated wealth must be annuitized; nominal amounts of savings paid in have to be guaranteed by providers). Certain types of occupational pension plans were captured by the definition, but the new framework was not ideal for actually using them in this context. The vast majority of relevant products therefore belonged to the domain of private, thirdpillar provisions. 
Originally, the plan had been to make purchases of suitable products mandatory for individuals covered in the public pension scheme. A rate of forced saving of 4 percent of gross earnings, to be phased in over several years, was considered sufficient to close the widening gap in retirement income which reductions in benefit levels of the public pension scheme would create over time. However, the idea of using compulsion to ensure participation and, hence, adequate benefit entitlements - as in the first pillar - met forceful public resistance. One reason was that, during a period of transition, contribution rates plus forced savings sounded like an unreasonably high burden, higher than when the public scheme would have been continued without any change. Another reason was wide-spread lack of experience with private old-age provision and even some mistrust in financial markets and financial intermediaries among average workers.

In this situation, politicians soon dropped the idea of imposing mandatory rules for supplementary provisions. With the "Riester pensions" that were finally enacted, ${ }^{18}$ participation was voluntary but publicly subsidized in order to induce people to choose appropriate amounts of additional cover. ${ }^{19}$ Subsidies are not only offered through deferred taxation as originally intended, but also through direct, state-financed co-payments. These co-payments are basically fixed (currently at 154 Euro per year, paid during the entire accumulation period) and have a strong child-related component (of another 185 Euro per child born until 2007, another 300 Euro per child born later, paid until children become economically independent), so that subsidization is much more pronounced for participants with low earnings or with several children. ${ }^{20}$ Eligible for the subsidization are all active members of Statutory Pension Insurance and their spouses (plus civil servants and their spouses, as their pension scheme was subjected to parallel reforms).

Take-up in this scheme was initially low, but then gained momentum. The number of contracts rose quickly between 2004 and 2010. Since then, the increase has slowed down and is now levelling off at a number of around 16 million (Federal Ministry of Labour and Social Affairs 2015). This figure needs to be corrected for contracts which have been terminated or abandoned (TNS Infratest 2012a, p. 33; Federal Statistical Office 2014). Also, the overall size of the target group of the scheme cannot easily be determined, because of the inclusion of spouses. ${ }^{21}$ Existing figures suggest that about one third of those who are eligible have actually been reached within more than 10 years since the scheme was implemented. This share may not grow much further under the current framework. Those who participate tend to have more children than average, which is fully in line with design features of the scheme. In addition, they have relatively high earnings and tend to be financially literate, while individuals with low earnings are clearly underrepresented, against the intentions and the form of subsidization (Bucher-Koenen 2011; Pfarr and Schneider 2013).

18 Named after the Federal Minister of Labour and Social Affairs who was responsible for this reform.

19 Nevertheless, the "recommended" savings rate of 4 percent was included in the formula for benefit up-ratings of the public pension scheme as if it were a legal levy, reducing annual up-ratings as long as it was phased in.

20 The required amount of savings of 4 percent of earnings is 216 Euro a year at the lower earnings threshold; 2,100 Euro per year is the corresponding upper limit on annual savings (year-2015 figures).

21 The sub-groups of those who are eligible by their employment status and those who are eligible through a marriage may overlap. Relevant information cannot be recovered from existing employment statistics 
It is possible that Riester pensions appear unattractive compared to other types of private old-age provision that individuals can engage in on a purely voluntary basis. It is also possible that subsidized plans simply displace other forms of savings for old age. However, apart from owner-occupied housing, private provision for old age has not been very wide-spread before the new scheme was established (TNS Infratest 2012b, pp. 28, 47-49). In-depth research has shown that reluctance to enter Riester contracts is related to wishes to buy housing property ${ }^{22}$ and to bequest motives (Börsch-Supan et al. 2008). Yet, with respect to other forms of financial old-age provision, there are indications of crowding-in, rather than crowding-out (Börsch-Supan et al. 2012). All in all, the programme therefore seems to be operational, but only with limited success in terms of coverage which can be achieved.

From the very beginning, this new type of supplementary provision was perceived as complicated and intransparent. It was also criticized for providing low effective rates of return and, specifically, for involving high fees. To deal with the first type of objections, a number of changes have been made over time that were meant to make information more accessible and to alleviate comparisons between competing products. Low returns are partly caused by guarantees (and other regulation of the business of providers) which are thought to be indispensable. To some extent, however, they result from the simple fact that private provision with individual counselling and marketing activities is always a high-cost approach. Also, even though rigorous assessments of the incidence are missing, one should probably not be surprised if the creation of a special market segment with certified products has led to opportunities for providers to extract substantial parts of the subsidies. Another drawback is that unexperienced customers may purchase products that are not ideal in terms of risks, expected returns and other conditions - if they do not end up buying nothing at all. When the scheme was initiated, examples already existed that were likely to perform much better regarding many of these aspects, such as the Swedish "Premium Pension” scheme which is fully mandatory and rather transparent, offering a standard portfolio as a meaningful default option and still giving individuals who are interested considerable discretion over their investment at rather low transaction costs.

Currently, returns on financial markets are low also as a consequence of the latest financial crisis. While losses in pension wealth during the early stage of the crisis have been limited in Germany (Gasche et al. 2010; Bucher-Koenen and Ziegelmeyer 2014), ${ }^{23}$ the potentially long-lasting impact on returns is very harmful with respect to all types of pre-funded old-age provision. Probably even worse, among workers as well as among politicians the crisis has further undermined trust in financial markets and existing providers which had been relatively weak from the very beginning. Especially those who have been reluctant to enter this field already before the crisis see low expected returns as an incentive to save less - not more, as they probably should (see Section 3.3). The resulting low diffusion of supplementary private provision is not only detrimental with respect to the adequacy of old-age income some time in the future. It actually jeopardizes the overall reform strategy of a shift

22 Since 2009, Riester plans can also be used as an instrument of saving for owner-occupied housing.

23 With respect to Riester contracts, this is simply due to existing regulation of investment. But is seems to apply on a broader scale to private provisions for old age in Germany. 
between unfunded and funded pillars. In the absence of broad-based, alternative sources of retirement income, politicians may be unable to continue the current reform path in the public pension scheme with respect to what is expected to happen after 2030 (see Section 2.3).

\subsection{Occupational pensions: A better platform for reaching high coverage?}

It is thus time to think about alternatives for the expansion of funded old-age provision that really work. Clearly, private provision could be made mandatory as originally intended. However, this would not automatically solve the problem of high costs, and it would definitely not solve the problem of a lack of trust which, in turn, makes it highly unlikely that such a change could be legislated in the near future. So what other options are there for increasing supplementary cover and making participation more binding, as much as this is needed?

Given the existing level of employer-based cover in Germany, occupational pensions might be more promising as a base for further expansions than purely private provisions. Riester pensions started at zero participation in 2002 and have now reached about 33 percent of active workers (and their spouses). Traditionally, other forms of private provision cover less than 10 percent of relevant sub-groups of the population, whether active or retired (TNS Infratest 2012b, pp. 47-49). At the same time, occupational pensions covered close to 50 percent of those in dependent employment in 2002, and this share has gone up to almost 60 percent until 2013 (TNS Infratest 2015, p. 12). ${ }^{24}$ As with purely private provisions, coverage provided through employers is lower for workers with low earnings. It is also low for workers in small and medium-sized enterprises, and there are differences in coverage between females and males or between East-Germany and West-Germany. But dealing with typical gaps of this kind could be easier than starting from scratch elsewhere.

The legal framework for occupational pensions has been amended more than once since the early 2000s (Buttler 2015, ch. 1, 8 and section 2.1), even though provisions of this kind were not meant to be a core element of the shift towards higher pre-funding. Most importantly, a new type of pension plans has been admitted (called "Pensionsfonds") which can be designed in line with current DCpractices and is subject to investment regulation that is far less restrictive than for other, more traditional types of plans. Also, employees now have a legal right to ask for deferred-compensation plans ("Entgeltumwandlung”, without financial participation of employers) even if their employers do not offer any form of occupational pensions. Especially this latter rule has contributed substantially to the recent expansion of employer-based old-age provision.

Another interesting development is that, in several branches of industry, social partners have turned their attention to the challenges involved in demographic ageing and included the topic of occupational pensions in collective agreements of considerable coverage. As a result, workers in these

24 These figures relate to occupational pensions provided in private businesses and in the public sector (where coverage is higher). They are based on a representative survey among providers, which may explain why results are higher than those obtained by surveying individuals (TNS Infratest 2012a, pp. 19, 27-32; 2012b, pp. 35-40, 102-108). Depending on the type of provisions, workers may not always be aware of the additional cover they have; also, some instruments are explicitly excluded in surveys of the latter type. 
industries ${ }^{25}$ can now choose between a small number of alternative plans which have been negotiated between representatives of employers and trade unions and are administered by professional providers of financial services. Premiums are typically shared between employers and employees, in a way which could be adjusted through collective re-negotiations and can be topped up by both parties on a voluntary basis. In most cases, workers can reject to contribute to any of the plans that are available if they do not want to (further) reduce current consumption to provide for (higher amounts of) supplementary cover at old age. In this case, they may forgo co-payments by employers, or these copayments may shrink to a minimum defined in the underlying agreement.

In the light of these trends, the option arises that German corporatism which clearly had its merits and disadvantages in the past could probably be used as a vehicle for further expanding supplementary old-age provisions. The result could be occupational pensions for a notable share of the labour force which are established and monitored through collective, industry-level agreements of social partners. As long as specific agreements made on this basis conform to certain (minimum) requirements, further public intervention may not be needed with regard to those covered there. In other sectors of industry - those where collective bargaining is not strong enough to set standards for total sectoral employment - more direct public intervention and more binding rules may be called for.

To trigger such a process and also to fill the gaps in coverage that remain, experience gathered in the Anglo-Saxon countries may be helpful, since funded provisions for old age have played a much more prominent role there for decades. The "Workplace Pensions" programme which is currently becoming effective in the UK provides a remarkable example for establishing a stringent framework for employer-based supplementary cover. Since 2012 (and until 2017 at the latest) employers have to provide and co-sponsor occupational pensions for their employees. Employees (above a certain earnings threshold) are subject to automatic enrolment, with the possibility of opting out (or opting back in, with automatic re-enrolment after 3 years), to make sure that only those stay out who are really convinced that they do not need additional cover. For employers who do not want to establish or select privately managed pension plans for this purpose, the National Employment Trust Fund (NEST) offers a reliable default solution which still leaves room for individual portfolio choices. Thus, the British approach does not rest on strict compulsion, but it reflects a number of insights from recent research on "behavioural finance” (Mitchell and Utkus 2004) regarding deficiencies of individual decisions to provide for old age in a suitable form. If participation of employers and employees is fully voluntary, as it is in the US, closing gaps in coverage becomes more difficult. But the "nondiscrimination" rules for 401(k) pension plans in the United States provide another potentially interesting approach, as they adjust tax incentives for employers in such a way that firms have an interest in actively including particular groups of employees.

25 The most important agreements of this type have been made for metal workers and for the chemical industry. Interestingly, the style of collective wage negotiations is very different in these two industries, rather aggressive in the first case, much more co-operative in the second one. In both cases, however, collectivebargaining institutions are very strong, which is probably a core condition for successfully addressing this issue in collective agreements in the first place. 
In Germany, a renewed strategy for expanding pre-funded old-age provision mainly in the second pillar could have important advantages over the current framework for third-pillar arrangements (see Section 3.1). First of all, offering a limited number of standardized products for larger groups of individuals would ease individual choice and should definitely reduce transaction costs. If these products are pre-selected and co-determined by social partners in certain industries, it can be expected that they are sufficiently tailored to specific needs of participants - and still allow for a sufficient degree of competition in financial markets. Last but not least, a central role of employers and representatives of workers might turn out to be a key element for (re-)establishing trust in products and providers as well as in the underlying strategy which, in turn, could render the on-going process of reforming the overall system of old-age provision credible and fully operational.

\subsection{How much pre-funding is needed?}

It is an interesting question per se how much retirement income would be required to maintain one's living standard at old age, and surprisingly little empirical research has directly dealt with this issue (Dudel et al. 2015). ${ }^{26}$ However, even though a considerable share of individuals may be myopic, rather than genuine life-cycle savers, public responsibility may be limited in this respect. An important benchmark for the replacement rate that needs to be taken care of by means of public compulsion or some other kind of useful framing is probably given by the benefit level - about 50 percent of gross earnings or 70 percent on a net-basis (see Section 2.3) - which had been secured by the public pension scheme at the out-set of the current reform path.

Figure 5 shows what is achieved in this respect under the current rules for subsidized, voluntary provisions in the third pillar and how this could possibly be strengthened through further reforms. As a baseline, however, the graph indicates what the public pension scheme alone will be able to deliver under current rules, taking into account the effects of longer working lives ("with 45 to 47 years of contributions"), as the statutory retirement age is increased by 2 years until around 2030 (and then kept constant at age 67). As a result, public pension benefits would remain constant at their current (gross) level of around 45 percent until 2030 and then start further declining to clearly less than 40 percent by 2060. If, on top of that, one third of the target group saves the "recommended" rate of 4 percent of their gross earnings (throughout, since relevant reforms were phased in), the average level of old-age pensions deriving from both unfunded and funded pillars will decline to around 43 percent in the long run. Those who save, however, will increase their benefit level to about 47 percent until 2030 and close to 50 percent until 2060. Almost the same could be accomplished for the average level of benefits, if (starting from 2016) participation would become mandatory, or at least much more binding than under existing rules, making sure that everyone who needs supplementary cover

26 Using longitudinal data on satisfaction with income to identify relevant effects, Dudel et al. (2015) find that a net replacement rate of about 85 percent is needed to keep the living standard unchanged when entering retirement. The result is surprisingly robust to changes in model specification and basically extends to the entire retirement period, if benefits are not all fully indexed to inflation. 
Figure 5: Benefits Deriving from a Multi-pillar System (1991-2060)

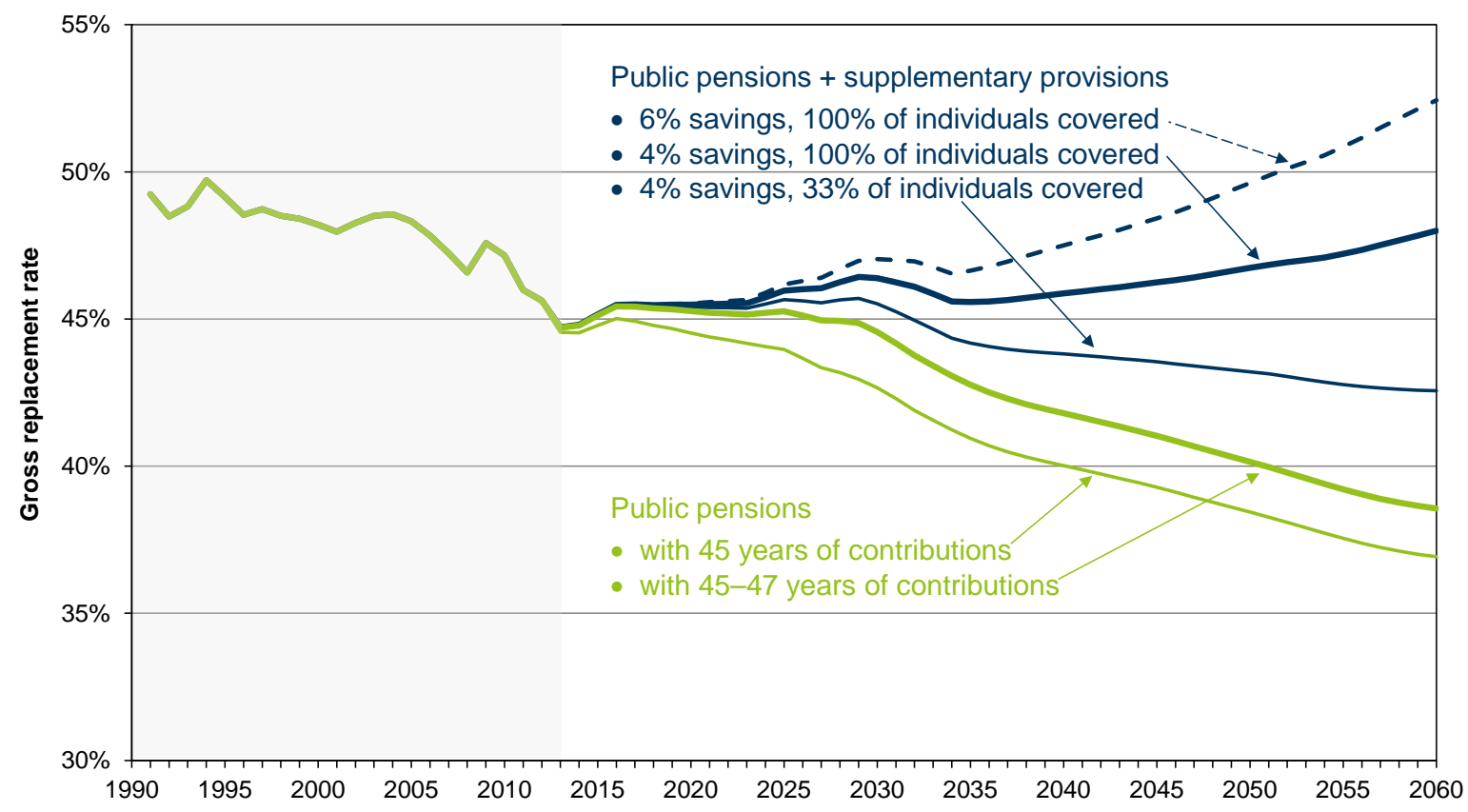

Sources: German Pension Insurance; SIM.13.

(“100 percent of individuals”) actually buys it. Note that supplementary pensions included here could derive from the second or third pillar - while additional considerations point to advantages of occupational pensions for really making this happen (see Section 3.2).

Another aspect is that a savings rate of 4 percent could still be too low to ensure adequate levels of pensions for the future. If contribution rates related to health insurance and costs of long-term care (plus income tax rates) increase, approaching historical gross levels of pension benefits may not be sufficient for this purpose. Instead, higher savings rates (of, say, “6 percent” of earnings, as shown in the figure) may be required. Also, the amount of retirement savings that is needed is a function of the rate of return. ${ }^{27}$ For the scenarios just described, we assume that real interest rates which are currently close to zero for low-risk assets in Germany recover to the long-term average rate of 3 percent p.a. (or 5 percent on a nominal basis) within relatively short time - until 2020, that is. If, instead, real returns remain below and then at 1.5 percent p.a. throughout the projection period, a savings rate of 6 percent will only deliver about the same benefit level as a 4-percent savings rate does under baseline assumptions. Without going into all relevant details, the scenarios considered here may serve as a preliminary illustration of what should be taken into account when further evolving the framework for supplementary old-age provision - as a necessary pre-condition for reforming the first-pillar scheme.

27 Note that this is not necessarily a consideration in terms of optimum life-cycle savings. Rather, we take as given a certain target level for the replacement rate of old-age income and check how it can be reached under variable interest rates. 


\section{Conclusions}

The German system of old-age provision is currently in the midst of a transition which is far from complete. The traditional pay-as-you-go public pension scheme fared surprisingly well through the recent period of the Great Recession. However, it is now heavily challenged by the expected consequences of demographic ageing which will become acute soon and will be very pronounced compared to other developed countries. A series of reforms taken since the 1990s has ensured financial viability of this scheme until around 2030. Nevertheless, further reforms are still needed to make the system fully sustainable in the long run.

The gradual reduction in benefit levels in the first pillar which is implied in the current legal framework calls for higher amounts of old-age income deriving from other sources. Demographic ageing means that pay-as-you-go financing meets serious limitations. The only alternative that exists, then, is an expansion of pension benefits which are genuinely pre-funded, searching for a new balance between different pillars of the overall system. Thus far, attempts at strengthening the third pillar in the context of recent reforms have been half-hearted. Some progress has been made in increasing coverage in private pension plans, but this involves only about one third of the target group, and this share may not grow much further under current rules. In addition, the existing framework leads to high transaction costs and requires unexperienced individuals to make difficult choices. What is needed are mandatory rules or, at least, a more stringent framing of individual decisions to participate. We have argued that occupational pensions might be a better vehicle for increasing coverage from supplementary sources of retirement income. Participation in this pillar has been much higher than in individual pension plans when Germany embarked on its pension reforms. In addition, employerbased provisions, probably co-determined by social partners in many industries, might offer an approach that is more in line with German traditions and institutions.

International experience may help in further reforming the current overall system. For example, to reduce costs and frame individual choices in third-pillar arrangements, the Swedish Premium Pension scheme might constitute a good example. A promising alternative for suitable regulation of second-pillar arrangements is offered by UK Workplace Pensions with auto-enrolment and an opt-out clause (or tax rules applied in the US, incentivating participation of particular groups of workers who are difficult to target). Following the reforms already taken, the room for manœuvre to stabilize the first pillar is now limited. ${ }^{28}$ In any case, additional increases in the statutory retirement age will be an issue in this context, probably with a rule-based approach following the Danish example. This is the only way to avoid further, direct reductions in benefit levels as a means to keep contribution rates from rising higher and higher over the next three to five decades.

28 Openly switching to a flat-rate system with basic pensions is difficult, due to legal and constitutional limits. With realistic scenarios, a reform of this kind will not remove financial pressure from the public pension scheme - only, there may be some savings in the separate scheme offering a minimum old-age income guarantee through means-tested benefits. A viable alternative might be offered by a gradual concentration of unfunded pension benefits on those who actually have children - in line with the economic fundamentals of pay-as-you-go financing - combined with higher amounts of precautionary savings for those who don't. 
However, German politicians are now very reluctant to promote pre-funded instruments of oldage provision in whatever form. This is mainly due to the recent financial crisis which has undermined trust in financial markets and in the strategy behind the series of earlier pension reforms. For the moment, it appears, the German system of old-age provision is trapped between the consequences of the latest crisis - although in different ways than many other national systems are - and an enormous ageing problem ahead.

\section{References}

Barr, Nicholas (2002), "Reforming pensions: Myths, truths, and policy choices”, International Social Security Review 55(2): 3-36.

Barr, Nicholas and Peter A. Diamond (2006), “The economics of pensions”, Oxford Review of Economic Policy 22(1): 15-39.

Börsch-Supan, Axel (2005), “What are NDC pension systems?”, in: Robert Holzmann and Edward Palmer (eds.), Pension Reform: Issues and Prospects of Non-Financial Defined Contribution (NDC) Schemes, Washington D.C.: World Bank, pp. 35-56.

Börsch-Supan, Axel, Anette Reil-Held and Daniel Schunk (2008), "Saving incentives, old-age provision and displacement effects: Evidence from the recent German pension reform”, Journal of Pension Economics and Finance 7(3): 295-319.

Börsch-Supan, Axel, Martin Gasche and Christina Benita Wilke (2009), Auswirkungen der Finanzkrise auf die Gesetzliche Rentenversicherung, ihre Beitragszahler und ihre Rentner, MEA Studies No. 9, Mannheim: Mannheim Research Institute for the Economics of Aging.

Börsch-Supan, Axel, Martin Gasche and Christina Benita Wilke (2010), "Konjunkturabhängigkeit der Gesetzlichen Rentenversicherung am Beispiel der aktuellen Finanz- und Wirtschaftskrise”, Zeitschrift für Wirtschaftspolitik 59(3): 298-328.

Börsch-Supan, Axel, Michela Coppola and Anette Reil-Held (2012), "Riester pensions in Germany: Design, dynamics, targeting success and crowding-in”, MEA Discussion Paper No. 20-2012. Börsch-Supan, Axel, Michela Coppola and Johannes Rausch (2015), “Die 'Rente mit 63': Wer sind die Begünstigten?“, Perspektiven der Wirtschaftspolitik 16(3): 264-288.

Breyer, Friedrich (1989), “On the intergenerational Pareto efficiency of pay-as-you-go financed pension systems”, Journal of Institutional and Theoretical Economics 145(4): 643-658.

Bucher-Koenen, Tabea (2011), "Financial literacy, Riester pensions, and other private old age provision in Germany”, MEA Discussion Paper No. 250-2011.

Bucher-Koenen, Tabea and Michael Ziegelmeyer (2014), "Once burned, twice shy? Financial literacy and wealth losses during the financial crisis”, Review of Finance 18(6): 2215-2246.

Buttler, Andreas (2015), Einführung in die betriebliche Altersversorgung, $7^{\text {th }}$ ed., Karlsruhe: Verlag Versicherungswirtschaft.

Cigno, Alessandro and Martin Werding (2007), Children and Pensions, Cambridge, MA, London: MIT-Press.

Coronado, Julia Lynn, Don Fullerton and Thomas Glass (2000), “The progressivity of social security”, NBER Working Paper No. 7520.

Diamond, Peter A. (2002), Social Security Reform, Oxford, New York: Oxford University Press.

Disney, Richard (1999), “Notional accounts as a pension reform strategy: An evaluation”, World Bank Social Protection Discussion Paper No. 9928. 
Disney, Richard (2003), “Public pension reform in Europe: Policies, prospects and evaluation”, The World Economy 26(10): 1425-1445.

Dudel, Christian, Notburga Ott and Martin Werding (2015), “Maintaining one’s living standard at old age: What does that mean? Evidence using panel data from Germany”, Empirical Economics (doi:10.1007/s00181-015-1042-8).

Ehrentraut, Oliver (2006), Alterung und Altersvorsorge: Das deutsche Drei-Säulen-System der Alterssicherung vor dem Hintergrund des demographischen Wandels, Frankfurt/Main: Peter Lang.

Federal Ministry of Labour and Social Affairs (2015), "Statistik zur privaten Altersvorsorge", http://www.bmas.de/DE/Themen/Rente/Zusaetzliche-Altersvorsorge/statistik-zusaetzlichealtersvorsorge.html (last accessed: 4 December 2015).

Federal Statistical Office (2014), Staatliche Förderung der Riesterrente 2010, Wiesbaden: Statistisches Bundesamt.

Fenge, Robert (1995), “Pareto-efficiency of the pay-as-you-go pension system with intragenerational fairness”, Finanzarchiv 52(3): 357-363.

Fenge, Robert and Martin Werding (2004), "Ageing and the tax implied in public pension schemes: Simulations for selected OECD countries”, Fiscal Studies 25(2): 159-200.

Gasche, Martin, Axel Börsch-Supan and Michael Ziegelmeyer (2010), “Auswirkungen der Finanzkrise auf die private Altersvorsorge”, Perspektiven der Wirtschaftspolitik 11(4): 383-406.

Gasche, Martin and Sebastian Kluth (2011), “Auf der Suche nach der besten Rentenanpassungsformel”, MEA Discussion Paper No. 241-2011.

Gruber, Jonathan and David A. Wise (eds., 2010), Social Security Programs and Retirement Around the World: The Relationship to Youth Employment, Chicago, London: University of Chicago Press.

Martin, John P. and Edward Whitehouse (2008), "Reforming retirement-income systems: Lessons from the recent experiences of OECD Countries”, OECD Social, Employment and Migration Working Papers No. 66.

Markus, Elena (2007), Alterssicherung in Deutschland: Umlagefinanzierung versus Kapitaldeckung, Saarbrücken: VDM Dr. Müller.

Meier, Volker and Martin Werding (2010), “Ageing and the welfare state: Securing sustainability“, Oxford Review of Economic Policy 26(4): 655-673.

Mitchell, Olivia S. and Stephen P. Utkus (eds., 2004), Pension Design and Structure: New Lessons from Behavioral Finance, Oxford, New York: Oxford University Press.

OECD (2015), “Real GDP, annual growth rate (\%)”, https://data.oecd.org/gdp/real-gdp-forecast.htm (last accessed: 30 November 2015).

Pestieau, Pierre (2006), The Welfare State in the European Union: Economic and Social Perspectives, Oxford, New York: Oxford University Press.

Pfarr, Christian and Udo Schneider (2013), “Choosing between subsidized or unsubsidized private pension schemes: Evidence from German panel data”, Journal of Pension Economics and Finance 12(1): 62-91.

Robalino, David A. and András Bodor (2007), “On the financial sustainability of earnings-related pension schemes with 'pay-as-you-go' financing and the role of government-indexed bonds”, Journal of Pension Economics and Finance 8(2): 153-187.

Sinn, Hans-Werner (2000), "Why a funded pension system is needed and why it is not needed", International Tax and Public Finance 7(4/5): 389-410. 
TNS Infratest (2012a), Verbreitung der Altersvorsorge 2011, Forschungsbericht No. 430, Berlin: Bundesministerium für Arbeit und Soziales.

TNS Infratest (2012b), Alterssicherung in Deutschland 2011 (ASID 2011), Forschungsbericht No. 431/Z, Berlin: Bundesministerium für Arbeit und Soziales.

TNS Infratest (2015), Trägerbefragung zur betrieblichen Altersversorgung (BAV 2013), Forschungsbericht No. 449/1, Berlin: Bundesministerium für Arbeit und Soziales.

Werding, Martin (2007), “Social insurance: How to pay for pensions and health care?”, in: Ingrid Hamm, Helmut Seitz and Martin Werding (eds.), Demographic Change in Germany: The Economic and Fiscal Consequences, Berlin, Heidelberg, New York: Springer, pp. 89-128.

Werding, Martin (2013), Modell für flexible Simulationen zu den Effekten des demographischen Wandels für die öffentlichen Finanzen in Deutschland bis 2060: Daten, Annahmen und Methoden, Gütersloh: Bertelsmann-Stiftung.

Werding, Martin (2014), “Demographischer Wandel und öffentliche Finanzen”, SVR-Arbeitspapier No. $1 / 2014$.

Werding, Martin (2016), Modellrechnungen für den vierten Tragfähigkeitsbericht des BMF, FiFoBericht No. 20, Köln: Finanzwissenschaftliches Forschungsinstitut an der Universität zu Köln. 


\section{Appendix A.1: Demographic projections}

Demographic projections for the simulations included in this paper have been prepared using the population module of SIM.13 (Werding 2013; see footnote 16). They are based on data for total population (differentiated by gender and single years of age) provided by the Federal Office of Statistics and on cohort-wise, year-by-year projections using the following assumptions for the "baseline” scenario.

- The total fertility rate remains constant at 1.4 (children per woman) over the entire projection period (as this has been the case, in West-Germany, since 1975)

- Life expectancy at birth goes up to 90.4 years for females and to 86.7 years for males until 2060 (current figures are 82.8 and 77.7 years, respectively)

- Net immigration is 150,000 individuals per year starting from 2020 (when current, higher figures have been phased out) throughout the projection period

Results for total population and old-age dependency (population aged 65 and over per 100 individuals in the population aged 15 to 64) under these assumptions are shown in Figures A.1 and A.2 below.

Given the uncertainties about the determinants of future demographic trends, alternative scenarios are also considered, using the following variations of baseline assumptions.

- Total fertility rate: \pm 0.2 children until 2060 (in a continuous process)

- Life expectancy at birth: \pm 2 years for both females and males in 2060

- Net immigration: $\pm 100,000$ per year throughout the projection period

Combining any of these assumptions yields 27 variants, of which two are considered to be particularly interesting. The "old population" scenario is based on assumptions implying declining fertility, a strong increase in life expectancy, and relatively low net migration. The "young population" scenario is based on assumptions implying increasing fertility, a weak increase in life expectancy, and relatively high net migration. Results for total population and old-age dependency for all these scenarios are included in Figures A.1 and A.2.

These projections do not reflect the unexpectedly high number of refugees which are currently arriving in Germany and may have added up to a total of 1 million individuals seeking asylum in the course of 2015. Thus far, too little is known about who these people really are, how long they are going to stay and, if so, how they will integrate into the labour market. To deal with this issue in a very preliminary fashion, another projection is added which is even more of a "what-if"-scenario than the other ones. The assumption is that 1 million refugees arrive in 2015 (instead of 250,000, as expected beforehand) and stay indefinitely, while there will be no further unexpected immigrants in subsequent years. The figures show that this has a visible effect for total population, but next to no impact on the time path of old-age dependency. If anything, the old-age dependency ratio is reduced by a tiny little margin until 2040 and increased by a little bit towards the end of the projection period. This is a typical result - and possibly an artefact - of the assumption that the extra-immigration comes as a temporary wave, not as a permanent flow. 
Figure A.1: Total population (2000-2060)

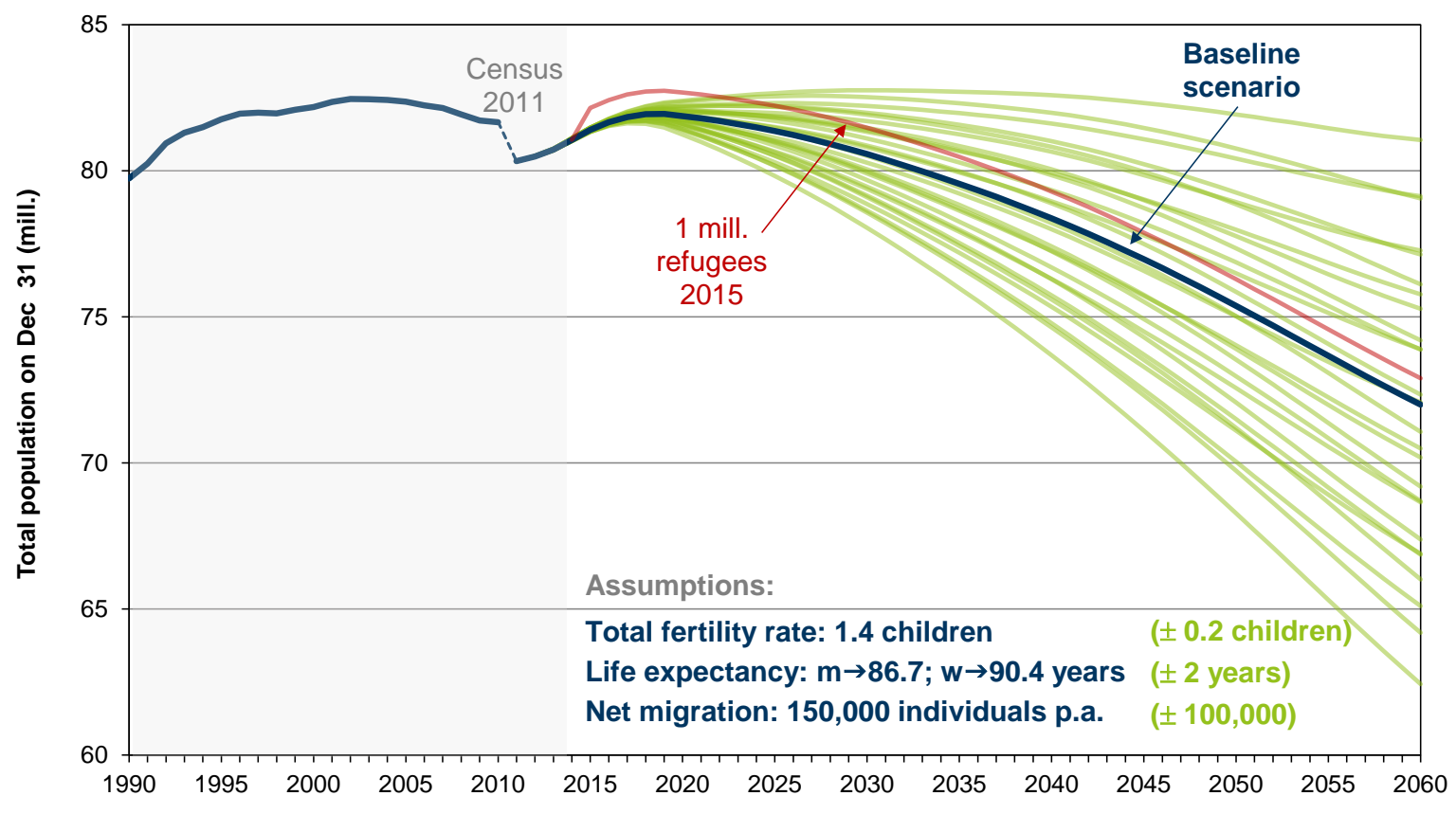

Figure A.2: Old-age dependency (2000-2060)

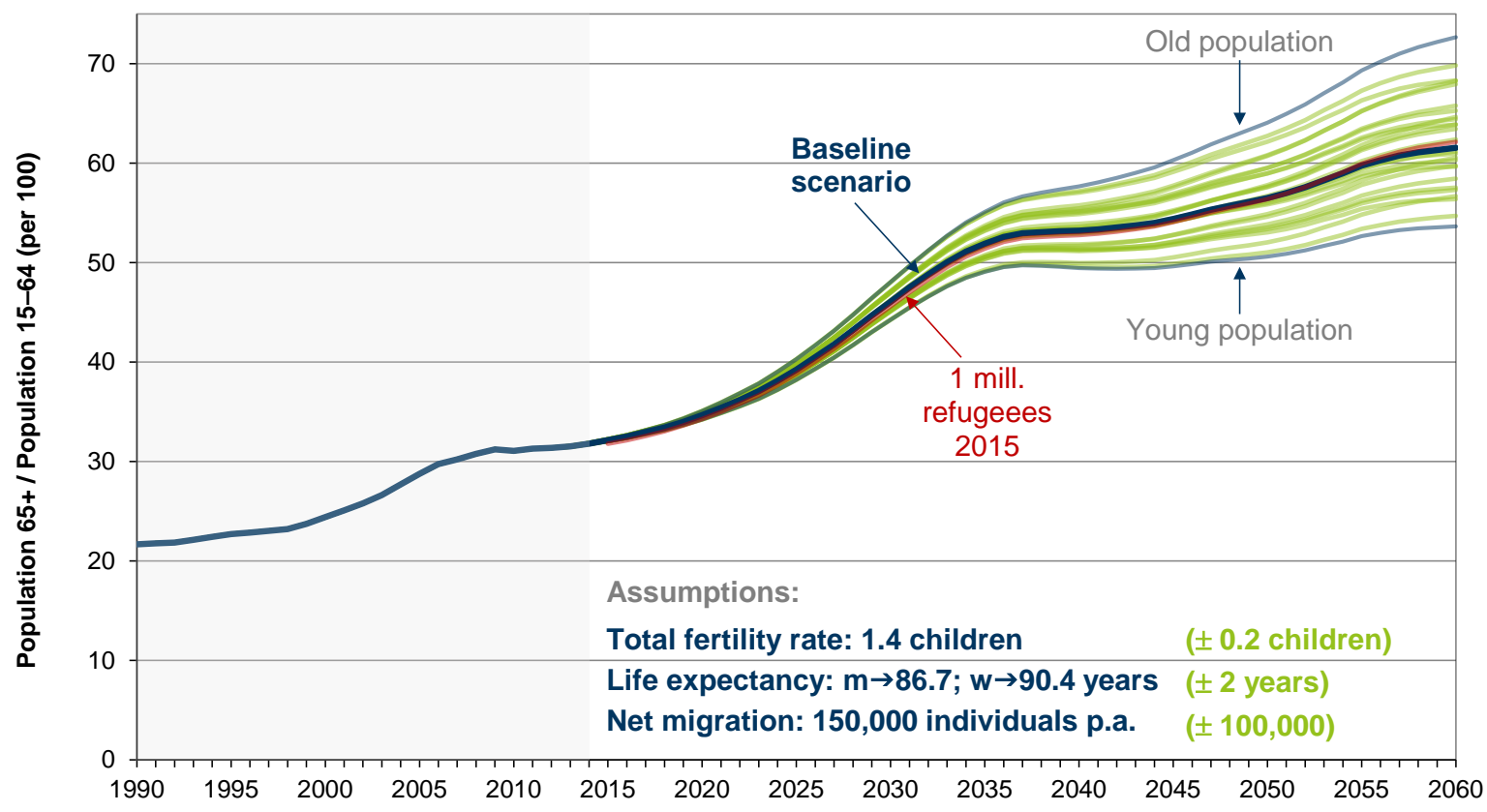

Sources: Federal Statistical Office; SIM.13. 


\section{Appendix A.2: Projections for the macro-economic background scenario}

Table A.1: Selected results for the "baseline" scenario

\begin{tabular}{|c|c|c|c|c|c|c|c|}
\hline & 2000 & 2010 & 2020 & 2030 & 2040 & 2050 & 2060 \\
\hline \multicolumn{8}{|l|}{ Demography: } \\
\hline Total population (mill.) & 82.2 & 81.7 & 81.9 & 80.6 & 78.4 & 75.4 & 72.0 \\
\hline Old-age dependency ratio ${ }^{a)}$ & 24.4 & 31.1 & 34.7 & 46.1 & 53.2 & 56.5 & 61.5 \\
\hline \multicolumn{8}{|l|}{ Labour market: } \\
\hline \multicolumn{8}{|l|}{ Participation rates (\%) } \\
\hline Females (15-64) & 68.9 & 74.6 & 81.0 & 83.2 & 83.5 & 84.0 & 84.5 \\
\hline Males (15-64) & 82.7 & 84.5 & 86.2 & 86.7 & 86.5 & 86.5 & 86.7 \\
\hline Labour force (mill.) & 42.9 & 43.8 & 45.7 & 43.2 & 40.2 & 38.3 & 35.6 \\
\hline Employment (mill.) & 39.9 & 41.0 & 43.9 & 41.3 & 37.9 & 35.6 & 32.8 \\
\hline Unemployment rate ${ }^{\mathrm{b})}(\%)$ & 7.3 & 6.4 & 4.1 & 4.5 & 6.0 & 7.2 & 7.9 \\
\hline \multicolumn{8}{|l|}{ Macro-economic development: } \\
\hline Labour productivity ${ }^{\mathrm{c}}$ (\%) & 1.4 & 0.6 & 1.0 & 2.0 & 2.0 & 1.8 & 1.7 \\
\hline $\mathrm{GDP}^{\mathrm{c})}(\%)$ & 1.7 & 0.9 & 1.6 & 1.4 & 1.1 & 1.1 & 1.0 \\
\hline GDP per capita ${ }^{\mathrm{c}}(\%)$ & 1.4 & 0.9 & 1.6 & 1.6 & 1.4 & 1.5 & 1.4 \\
\hline Interest rate $^{\mathrm{d})}(\%)$ & 3.8 & 1.3 & 3.0 & 3.0 & 3.0 & 3.0 & 3.0 \\
\hline \multicolumn{8}{|c|}{$\begin{array}{l}\text { Year-2010 figures are actual values taken from official sources; results reported for the years from } 2020 \\
\text { onwards are projections, based on many assumptions, never prognoses. }\end{array}$} \\
\hline \multicolumn{8}{|c|}{$\begin{array}{l}\text { a) Population aged } 65 \text { and older per } 100 \text { individ } \\
\text { b) Percentage of the total labour force (ILO defi } \\
\text { c) Annualized } 10 \text {-year real growth rates. }\end{array}$} \\
\hline
\end{tabular}

Sources: Federal Statistical Office; Federal Employment Agency, Bundesbank; SIM.13. 